\title{
Inhibitory potential of chemical substitutions at bioinspired sites of $\beta$-D-galactopyranose on neoglycoprotein/cell surface binding of two classes of medically relevant lectins
}

\author{
Denis Giguère ${ }^{\mathrm{a}}$, Sabine André ${ }^{\mathrm{b}}$, Marc-André Bonin ${ }^{\mathrm{a}}$, Marc-André Bellefleur ${ }^{\mathrm{a}}$, Alexandre Provencal ${ }^{\mathrm{a}}$, \\ Philipe Cloutier ${ }^{\mathrm{a}}$, Bernard Pucci ${ }^{\mathrm{c}}$, René Roy ${ }^{\mathrm{a}, *}$, Hans-Joachim Gabius ${ }^{\mathrm{b}, *}$ \\ a PharmaQAM, Department of Chemistry, Université du Québec à Montréal, PO Box 8888, Succ. Centre-ville, Montreal (QC), H3C 3P8, Canada \\ ${ }^{\mathrm{b}}$ Institute of Physiological Chemistry, Faculty of Veterinary Medicine, Ludwig-Maximilians-University, Veterinärstr. 13, D-80539 Munich, Germany \\ ${ }^{\mathrm{c}}$ Laboratoire de Chimie Bioorganique et des Systèmes Moléculaires Vectoriels, Université d'Avignon et des Pays du Vaucluse, Faculté des Sciences, 33 rue Louis Pasteur, F-84000 \\ Avignon, France
}

\section{A R T I C L E I N F O}

\section{Article history:}

Received 2 December 2010

Revised 4 March 2011

Accepted 9 March 2011

Available online 30 March 2011

\section{Keywords:}

Agglutinin

Blood group

Glycocluster

Malignancy

Multivalency

Neoglycoconjugate

\begin{abstract}
A B S T R A C T
Galactose is the key contact site for plant AB-toxins and the human adhesion/growth-regulatory galectins. Natural anomeric extensions and $3^{\prime}$-substitutions enhance its reactivity, thus prompting us to test the potential of respective chemical substitutions of galactose in the quest to develop potent inhibitors. Biochemical screening of a respective glycoside library with 60 substances in a solid-phase assay was followed by examining the compounds' activity to protect cells from lectin binding. By testing 32 anomeric extensions, 18 compounds with additional 3'-substitution, three lactosides and two Lewis-type trisaccharides rather mild effects compared to the common haptenic inhibitor lactose were detected in both assays. When using trivalent glycoclusters marked enhancements with 6- to 8-fold increases were revealed for the toxin and three of four tested galectins. Since the most potent compound and also 3'substituted thiogalactosides reduced cell growth of a human tumor line at millimolar concentrations, biocompatible substitutions and scaffolds will be required for further developments. The synthesis of suitable glycoclusters, presenting headgroups which exploit differences in ligand selection in interlectin comparison to reduce cross-reactivity, and the documented strategic combination of initial biochemical screening with cell assays are considered instrumental to advance inhibitor design.
\end{abstract}

(c) 2011 Elsevier Ltd. All rights reserved.

\section{Introduction}

The complexity of cell surface glycoconjugates features all attributes to cover a wide variety of biochemical signals. ${ }^{1}$ One route to decode this information is via specific receptors. The emerging functionality of the molecular recognition of distinct glycan determinants by proteins (lectins) is therefore unraveling new targets for rational drug design, a demanding challenge for chemical biology. ${ }^{2,3}$ In fact, carbohydrates, their derivatives and mimetics offer the promising perspective to block certain lectin effectors specifically, for example, in developing heart failure, inflammatory diseases or progression of malignancy. ${ }^{4-7}$ To do so successfully, the cross-reactivity of a lectin-blocking compound with other sugar receptors, especially members from the same family, must be minimal, while reaching an optimal affinity for its target. Thus, any differences in folding and sequence deviations among homologous

\footnotetext{
* Corresponding authors. Tel.: +1 (514) 987 3000x2546; fax: +1 (514) 9874054 (R.R.); tel.: +49 892180 2290; fax: +49 8921802508 (H.-J.G.).

E-mail addresses: roy.rene@uqam.ca (R. Roy),gabius@tiph.vetmed.uni-muenchen.de (H.-J. Gabius).
}

proteins need to be exploited toward the aim to develop selective high-affinity inhibitors.

In the quest to explore to what extent substitutions of the core contact site can improve inhibitory potency, we here focus on two classes of galactose-binding lectins, that is, a plant toxin (Viscum album agglutinin (VAA) with $\beta$-trefoil folding) and four human adhesion/growth-regulatory galectins selected to represent the three subgroups within this family ( $\beta$-sandwich folding). ${ }^{8-10}$ Our study thus investigates the relative inhibitory capacity of galactose derivatives in interectin and intralectin family comparison. These two classes of lectins are known to favor a natural 3'-substitution of galactose and also $\beta$-anomeric elongations beyond the core unit, that is, by $N$-acetyllactosamine repeats, inspriring structural additions at these sites. ${ }^{11-15}$ The concept for our study is put into graphics in Figure 1, showing that these two types of substitutions can contact the protein's surface (here human galectin-3). Since lactose binding is known to induce conformational changes in these two lectin classes, ${ }^{16-19}$ high-affinity carbohydrate derivatives will not only serve as sensors for inter- and intrafamily differences but will also become tools to detect ligand-induced alterations upon structural study. Their synthesis will also answer the 


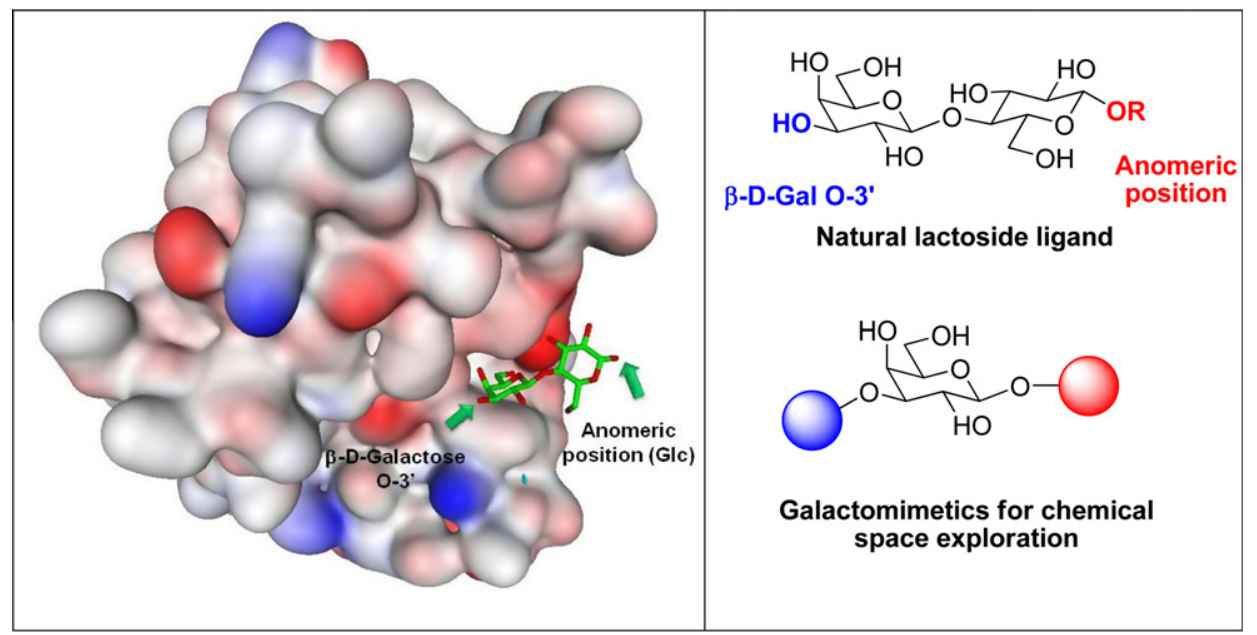

Figure 1. Connolly surface of human galectin-3 cocrystallized with lactose (PDB 2NN8) with the depiction of the two bioinspired sites of substitution.

question to what extent chemical substitutions can compete with natural glycans.

In this report, we tested a library of 60 synthetic compounds covering four groups based on type of substitution and extension as well as degree of valency: $32 \beta$-D-galactopyranoside derivatives (1-32) with anomeric extension via C/O-glycosidic bonds (Scheme 1), 18 S-linked derivatives (33-50) with additional 3'-substitution of the galactose core (Scheme 2), three lactose derivatives (51-53) and two Lewis-type trisaccharides $(\mathbf{5 4}, \mathbf{5 5})$ (Scheme 3 ) as well as three bi- to trivalent glycoclusters $(\mathbf{5 6}, \mathbf{5 9}, \mathbf{6 0})$ with two monovalent control derivatives $(\mathbf{5 7}, \mathbf{5 8})$ bearing the long F-containing spacer (Scheme 4). As noted above, the introduction of diverse chemical groups at the anomeric center and at the $3^{\prime}$-site was intended to mimic natural ligands and to exploit this region of the lectins' surface for affinity generation (Fig. 1). Besides substitutions of the core ligand binding to lectins can further be enhanced by an increase in valency, especially when the topologies of lectin-site/ glycan displays match or ligands are presented in microdomains. ${ }^{20-23}$ To probe into the relative effect of bi- to trivalency in the same experimental setting we included the three glycoclusters $\mathbf{5 6}, \mathbf{5 9}, \mathbf{6 0}$ into the test panel. The screening process was strategically designed in two levels of increasing biorelevance, starting with an inhibition assay in which the labeled lectin (in solution) in microtiter plate wells binds to a surface-presented ligand. ${ }^{24}$
Since the anomeric extension by a phenyl group is known to enhance binding for the toxin and galectin- $1,{ }^{25-30}$ we used a neoglycoprotein with such a spacered lactose moiety as strong ligand mimetic. Thus, we set rather restrictive conditions for blocking lectin binding by the test compounds relative to lactose as internal reference.

In the second activity-assessment stage, we increased the biorelevance by testing the synthetic compounds as inhibitors of lectin binding to human tumor cells, which present natural highaffinity ligands. In addition to this two-step assay process we addressed the issue whether such substitutions can convey cytotoxicity to galactose/lactose. This study thus answers the questions on inter- and intrafamily differences inferred by these chemical sensors, their activity as inhibitors of lectin binding to physiological cell surface glycans and their potential for cytotoxicity, strategically combining chemical synthesis with biochemical/cell biological assays.

\section{Results and discussion}

\subsection{Chemistry}

The test panel was divided into four groups (Schemes 1-4) to enable dissection of the relative impact of the different types of<smiles>COC(=O)/C=C/CC(O)C(O)C(O)OCO</smiles>

1

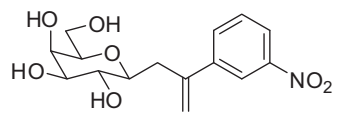

6

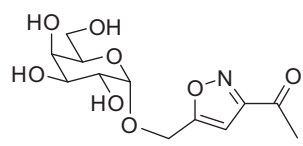

12<smiles>OC(O)C(O)C(O)CCC=Cc1ccccc1</smiles>

2<smiles>CC(=O)CCOC(O)C(O)OC(O)C(C)CO</smiles>

7

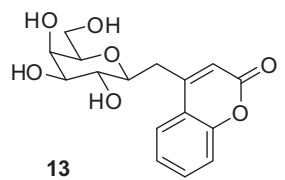

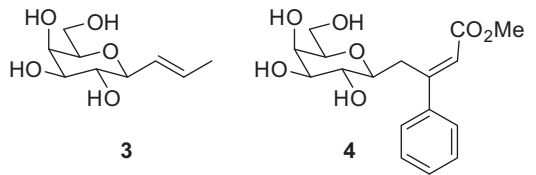<smiles>C=C(CC(O)C(O)C(O)O)c1ccc(OC)cc1</smiles>

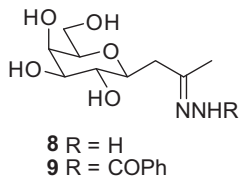

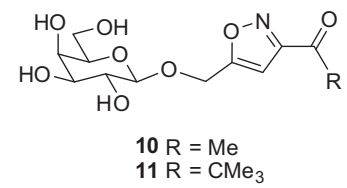

$14 \mathrm{R}=\mathrm{H} ; 15 \mathrm{R}=\mathrm{COMe} ; 16 \mathrm{R}=\mathrm{CO}_{2} \mathrm{Me}$ $17 \mathrm{R}=\mathrm{SO}_{2} \mathrm{Ph} ; 18 \mathrm{R}=\mathrm{SO}_{2} \mathrm{Ph}-\mathrm{pMe}$ $19 \mathrm{R}=\mathrm{SO}_{2} \mathrm{Ph}-p \mathrm{Br} ; 20 \mathrm{R}=\mathrm{SO}_{2} \mathrm{Ph}-p$ - $\mathrm{B}$ $21 \mathrm{R}=\mathrm{SO}_{2} \mathrm{Ph}-m \mathrm{Cl} ; 22 \mathrm{R}=\mathrm{SO}_{2} \beta$-naphthyl $23 \mathrm{R}=\mathrm{SO}_{2} \mathrm{Ph}-2,5-\mathrm{Br}_{2}$

$23 \mathrm{R}=\mathrm{SO}_{2} \mathrm{Ph}-2,5-\mathrm{Br}_{2}$
$24 \mathrm{R}=\mathrm{COPh} ; 25 \mathrm{R}=\mathrm{COPh}-\mathrm{pOMe}$ $26 \mathrm{R}=\mathrm{COPh}-p \mathrm{NO}_{2} ; 27 \mathrm{R}=\mathrm{COPh}-\mathrm{pBr}$ $28 \mathrm{R}=\mathrm{CO} \beta$-naphthyl; $29 \mathrm{R}=\mathrm{COCH}_{2} \mathrm{Ph}$ $30 \mathrm{R}=\mathrm{CH}_{2} \mathrm{Ph} ; 31 \mathrm{R}=\mathrm{CH}_{2} \mathrm{Ph}-p \mathrm{OMe}$ $32 \mathrm{R}=\mathrm{CH}_{2} \mathrm{Ph}-p \mathrm{NO}_{2}$ 


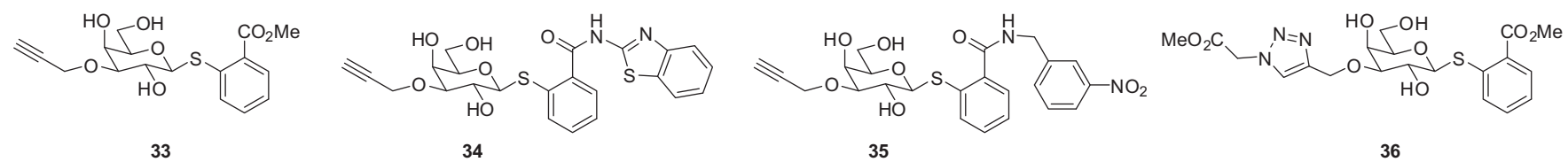

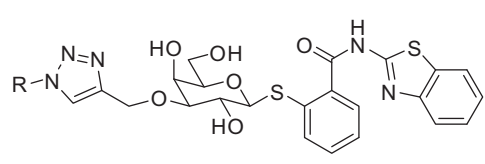

$37 \mathrm{R}=\mathrm{CH}_{2} \mathrm{Ph}$

$38 \mathrm{R}=\mathrm{CH}_{2} \mathrm{Ph}-\mathrm{pOH}$

$39 \mathrm{R}=\mathrm{CH}_{2} \mathrm{CH}_{2} \mathrm{OH}$

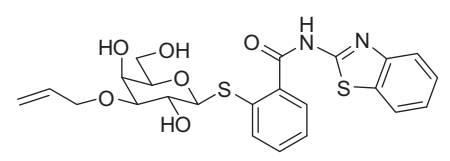

48

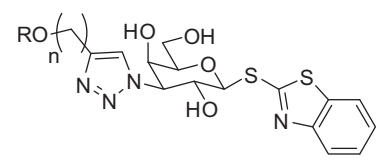

$40 \mathrm{n}=1, \mathrm{R}=\mathrm{SO}_{3} \mathrm{Na}$

$41 \mathrm{n}=2, \mathrm{R}=\mathrm{SO}_{3} \mathrm{Na}$

$42 \mathrm{n}=2, \mathrm{R}=\mathrm{PO}_{3} \mathrm{Ph}$

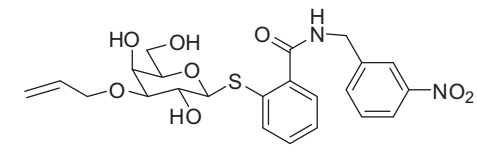

49

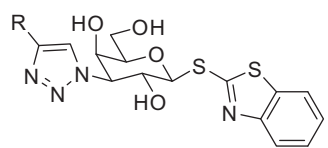

$43 \mathrm{R}=\mathrm{Ph}$

$44 \mathrm{R}=\mathrm{CH}_{2} \mathrm{OH}$

$45 \mathrm{R}=\mathrm{CH}_{2} \mathrm{CH}_{2} \mathrm{OH}$

$46 \mathrm{R}=\mathrm{CO}_{2} \mathrm{Me}$

$47 \mathrm{R}=\mathrm{CO}_{2} \mathrm{H}$

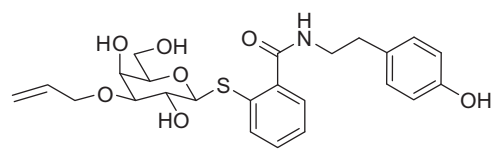

50

Scheme 2. 3'-Extension of $\beta$-D-galactopyranoside derivatives.
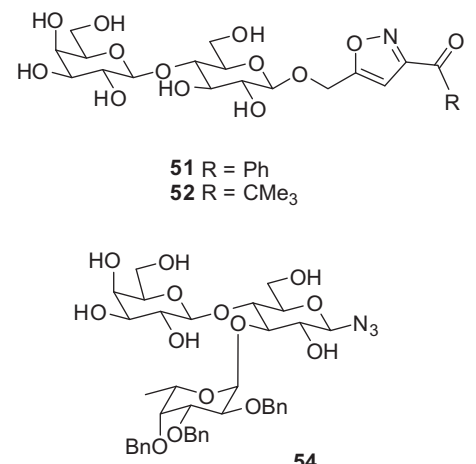

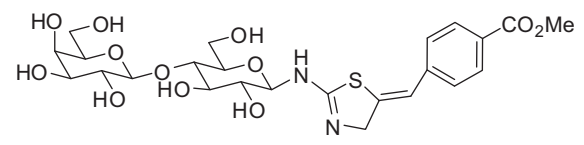

53

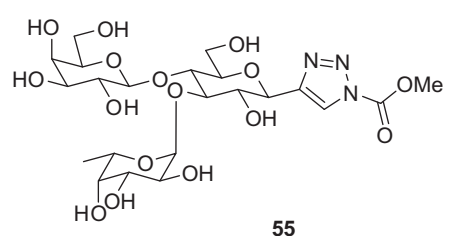

55

Scheme 3. Lactose derivatives.

substitution on lectin binding. In the first category, diverse aglycones were added to the galactopyranose core in $\beta$-anomeric linkage, mostly with non-hydrolyzable C-glycosidic linkage (Scheme 1). ${ }^{28-37}$ For instance, C-allylated acrylate $\mathbf{1}^{36}$ served as a versatile starting material for most of the derivatizations in the first series (Scheme 1), while the methyl ketone 7 provided access to the aminothiazole series Scheme 5$).{ }^{36}$ In order to probe for the effects of the bioinspired modification at the 3'-hydroxyl group of galactose a further panel of 18 derivatives (33-50) ${ }^{34,35}$ (see Supplementary data) with different types of substitution at this site in addition to those at the anomeric center was synthesized (Scheme 2). These compounds will thus answer the question whether the prepared mimetics of natural glycans can surpass their affinity. In our cases, 2-(methoxycarbonyl)phenyl 3-O(prop-2-enyl)-1-thio- $\beta$-D-galactopyranoside $(\mathbf{3 3})^{35}$ served as the starting material for this series, while a 3 -azido galactoside derivative $^{31}$ started the route to compounds $\mathbf{4 0 - 4 7 . 3 4 , 3 5}$ In order to determine the effect of anomeric extension of lactose relative to galactose, thus probing into a further distal region of the lectin sites, five such derivatives (51-55) $)^{32}$ were included (Scheme 3 ). Compound $\mathbf{5 3}$ has been reported previously in the literature ${ }^{38}$ and served as comparison already used for construction of lectinreactive glycodendrimers. ${ }^{39,40}$ Comparison between the three groups of monovalent compounds and the glycoclusters is a means to infer the relative potential of these two synthetic strategies to generate potent inhibitors. Of note, the long-chain fluorinated spacers of compounds 57-59 are known to form micelles at the tested concentration ${ }^{41,42}$, adding a topological aspect to the di$(\mathbf{5 6})^{36}$ and trivalent glycoclusters $(\mathbf{6 0})^{29}$ (Scheme 4$)$.

\subsection{Inhibition assays (glycoprotein)}

This library of 60 synthetic compounds was tested for activity to block lectin binding to a ligand. Besides considering different folding ( $\beta$-trefoil and $\beta$-sandwich) we studied the aspect of intrafamily reactivity pattern by selecting galectins from the three subgroups, that is, homodimeric proto-type (galectin-1), chimera-type (galectin-3) and tandem-repeat-type (galectins-8 and -9) proteins. The functional competition, up to now detected for galectins- 1 and $-3,{ }^{43,44}$ signifies differential cross-linking properties, an indication for disparate reactivity with glycoclusters. Each lectin was labeled and rigorously checked for maintained binding properties. A neoglycoprotein with $p$-isothiocyanatophenyl lactosides ${ }^{24}$ as ligand was adsorbed to the plastic surface of microtiter plate wells to establish a lectin-binding matrix. The parameters of coating density and lectin concentration were systematically examined to define the conditions, which yielded a linear range for dependence of signal intensity from lectin concentration and a sugar-inhibitable binding. Controls with non-cognate sugars (mannose, maltose) excluded non-specific effects. Under these subsaturating conditions systematic titrations for each derivative and each lectin were performed to determine the compound concentration required to 

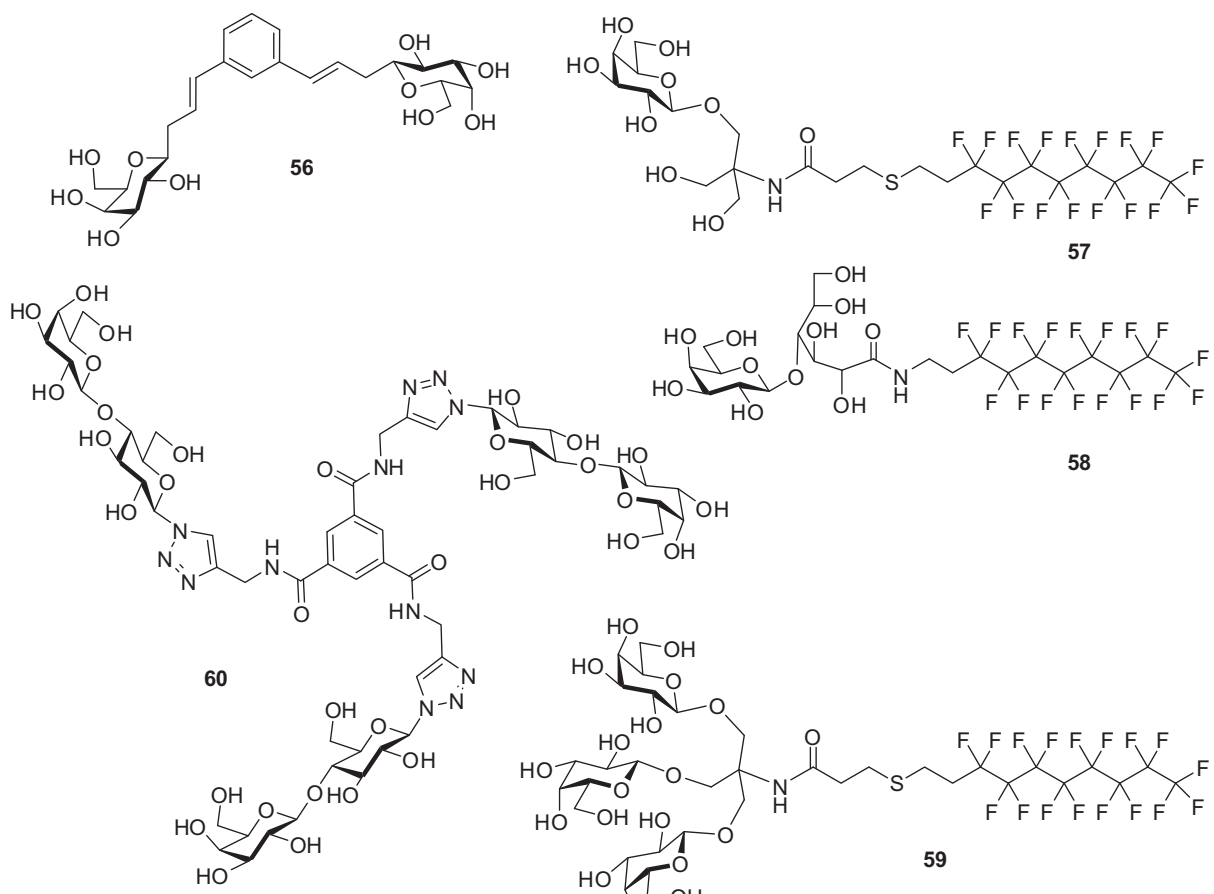

Scheme 4. $\beta$-D-Galactopyranoside and lactoside clusters with a monovalent control.
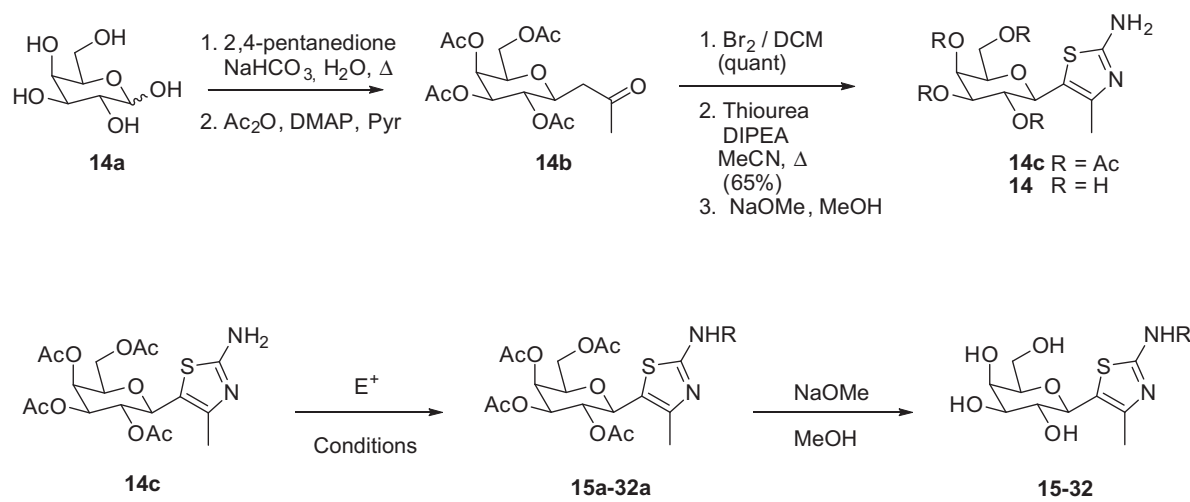

Scheme 5. Synthetic strategy to obtain the aminothiazole series.

reach $50 \%$ inhibition $\left(\mathrm{IC}_{50}\right)$ of binding, using lactose as internal reference.

The systematic testing revealed a remarkable relative activity level of the natural disaccharide. Two monovalent galactose derivatives and three 3 '-modified galactosides surpassed its inhibitory capacity (Table 1, Fig. 2). The contact area in the plant toxin for an anomeric extension is thus rather limited, in accord with the mapping of contacts via saturation transfer difference NMR spectroscopy, and the synthetic core modifications did not appear to reach the level of activity of the natural $\alpha 1,3-$ linked digalactoside. ${ }^{12,25,45,46}$ The Lewis-type trisaccharides were not active, corroborating previous chemical mapping of the relative importance of hydroxyl groups with methyl $\beta$-lactoside analogues. ${ }^{17,47}$ An anomeric extension beyond lactose showed slight improvements for three of four galectins, here the chimera-type galectin- 3 and the two tandem-repeat-type galectins- 8 and -9 (Table 1, Fig. 2). This result is in line with our previous report under identical conditions that anomeric extensions, especially the $S$-lactosides of $\beta$-naphthyl sulfone and 2-benzothiazolyl, can improve reactivity, pointing to
Table 1

Relative potency of synthetic compounds based on $\mathrm{IC}_{50}$-values relative to lactose ${ }^{\mathrm{a}}$

\begin{tabular}{llllll}
\hline Lectin compound & VAA & Gal-1 & Gal-3 & Gal-8 & Gal-9 \\
\hline $\mathbf{2 4}$ & 1.2 & -- & 1.3 & -- & -- \\
$\mathbf{2 9}$ & 1.3 & -- & 1.1 & -- & -- \\
$\mathbf{3 3}$ & -- & -- & 1.8 & -- & -- \\
$\mathbf{4 0}$ & -- & -- & -- & -- & 1.4 \\
$\mathbf{4 7}$ & -- & -- & 1.4 & -- & -- \\
$\mathbf{5 2}$ & -- & -- & 1.6 & 2.2 & 1.7 \\
$\mathbf{5 6}$ & 1.9 & -- & -- & -- & -- \\
$\mathbf{5 9}$ & 2.2 & 1.8 & 6.2 & 4.6 & 5.1 \\
$\mathbf{6 0}$ & 6.2 & -- & 8.4 & 6.9 & 7.7 \\
\hline
\end{tabular}

a The concentrations yielding a $50 \%$-level of inhibition of lectin binding to lactosylated neoglycoprotein were calculated as sugar content and normalized to free lactose; all data are given for compounds surpassing the potency of the internal control. Data represent assay results routinely done in triplicates for up to five independent series with nine concentrations, standard deviations not exceeding $15.5 \%$. 


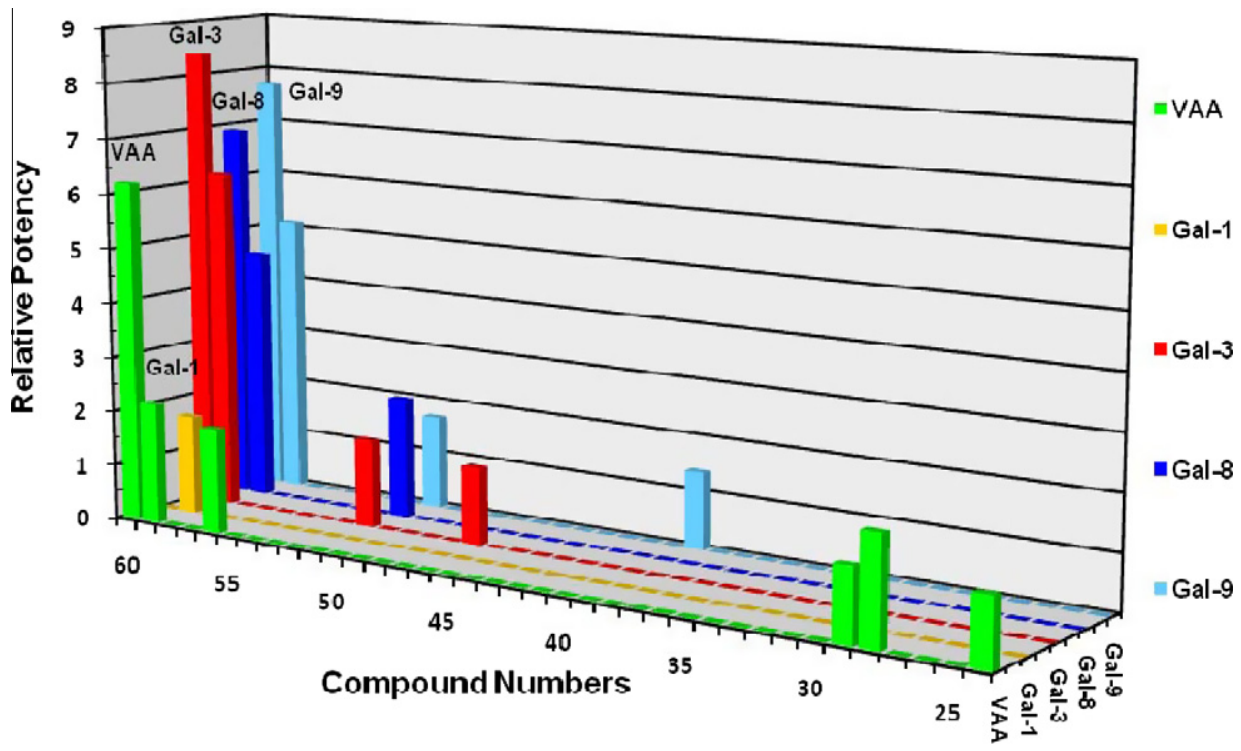

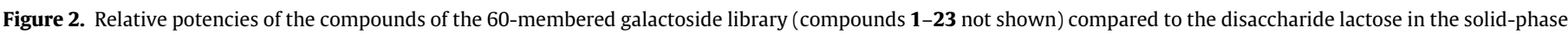
inhibition assay (please see footnote to Table 1 for details).

an extended contact site for several galectins. ${ }^{24}$ The most notable effects were yet seen with bi- to trivalent compounds $\mathbf{5 6}, \mathbf{5 9}, \mathbf{6 0}$ (Table 1, Fig. 2). The two trivalent clusters $\mathbf{5 9 ,} 60$ reached enhancements up to 6- or 8-fold, respectively, with galectins-3, -8 and -9 (Fig. 2, Table 1). Thus, while the anomeric extensions tested, even in combination with $3^{\prime}$-substitutions at the galactose core, did not markedly surpass the capacity of lactose as inhibitor, clustered ligand presentation has a comparatively strong effect. Of note, intrafamily cross-reactivity can occur within this library under these assay conditions using a carrier-immobilized lactose derivative as ligand. In the medical context, the ligands will be natural glycans with variations in structure and in topological presentation. To what extent the synthetic compounds will interfere with the binding of lectins to their natural high-affinity ligands on cell surfaces was an open question. To address this issue we performed cell assays by using each constituent of the glycoside library as inhibitors of binding of the labeled lectin to human tumor cells.

\subsection{Inhibition assays (cells)}

Concentration dependence of the signal intensity was tested for each combination of lectin and cell line at a constant cell number $\left(5 \times 10^{4}\right)$ per assay. A representative plot is exemplarily shown in Figure $3 \mathrm{~A}$ in the case of the plant toxin VAA. Lectin binding could completely be blocked by lactose in each case, while maltose or mannose used as osmolarity control did not affect staining properties (not shown). Monitoring of positivity in the cell population (in percent) and the mean fluorescence intensity was always run in parallel with inherent positive and negative controls on aliquots of cell suspensions of the same passage. When systematically using galactose/lactose concentrations with weak to medium effects on extent of staining and the test compounds at the same concentration in parallel, several substances could be singled out to interfere with lectin binding to the cell surface more potently than the unsubstituted sugars. This set gave a complete match to the data from solid-phase screening. The two assays thus identified activity for the same panel of compounds. The assay sensitivity is underscored by picking up the increased reactivity of lactose compared to galactose (Fig. 3B, C). In correlation with the results of the solid-phase assays, toxin binding to cells was reduced most potently by the glycoclusters $\mathbf{5 9}$ and $\mathbf{6 0}$ when used at the same concentration (normalized to sugar content) as the free sugar (Fig. 3B). The two thiazolyl galactoside derivatives $\mathbf{2 4}$ and $\mathbf{2 9}$ listed in Table 1 also passed the inherent activity threshold in the cell assay (Fig. 3C). Further focusing on the identification of best-activity cases, it is clear that the increase in valency, as best exemplified by the trivalent glycocluster $\mathbf{6 0}$, is quantitatively more suited to generate enhanced inhibitory capacity than synthetic derivatization within this panel. Because galectins can share common ligands such as the pentasaccharide of ganglioside GM1 but also have the potential for cell- and lectin-type-specific binding, ${ }^{7,43,44}$ inhibitory capacity and extent of cross-reactivity were analyzed with four members of this family in parallel.

As noted above, inhibitory potency for compounds active in the solid-phase assay was maintained in the competition with the cell surface glycans. The trimeric glycoclusters 59 and 60 surpassed all other compounds significantly for galectin-3, reaching an about 7fold enhancement relative to free lactose (Fig. 3D, E). To exclude that this effect was attributable to the nature of the cell line, we tested a T-cell leukemia and a colon adenocarcinoma line and determined a rather similar extent of avidity increase (Fig. 3E, F). Similar levels of potency, a clear sign for intergalectin cross-reactivity, were measured for galectins- 8 and -9 , corroborating the solid-phase data (Fig. 3G, H). These results indicate that an initial screening step by the biochemical assay is feasible and that the hereby identified compounds also stand out from the panel in cell assays, where lectins home in on physiologic ligands. However, this activity does not necessarily qualify such compounds as medically relevant lectin inhibitors. An essential prerequisite is to show lack of cytotoxicity.

\subsection{Cytotoxicity}

To address this issue, we monitored cell proliferation in aliquots of suspensions of human SW480 colon adenocarcinoma cells after a period of $48 \mathrm{~h}$ in culture, adding experimental series with galactose and lactose as controls. Six synthetic compounds were added to medium at concentrations of $1,2,5$, and $10 \mathrm{mM}$. The substituted galactosides 3, 22 and $\mathbf{2 5}$ did not affect proliferation at $2 \mathrm{mM}$, an increase to $5 \mathrm{mM}$ decreasing growth to $50-70 \%$ values. The $3^{\prime}-$ substituted galactoside $\mathbf{4 7}$ reduced growth to about $40 \%$ at $2 \mathrm{mM}$ (70\% at $1 \mathrm{mM}$ ), the $3^{\prime}$-substituted $S$-galactoside $\mathbf{3 3}$ most potently 

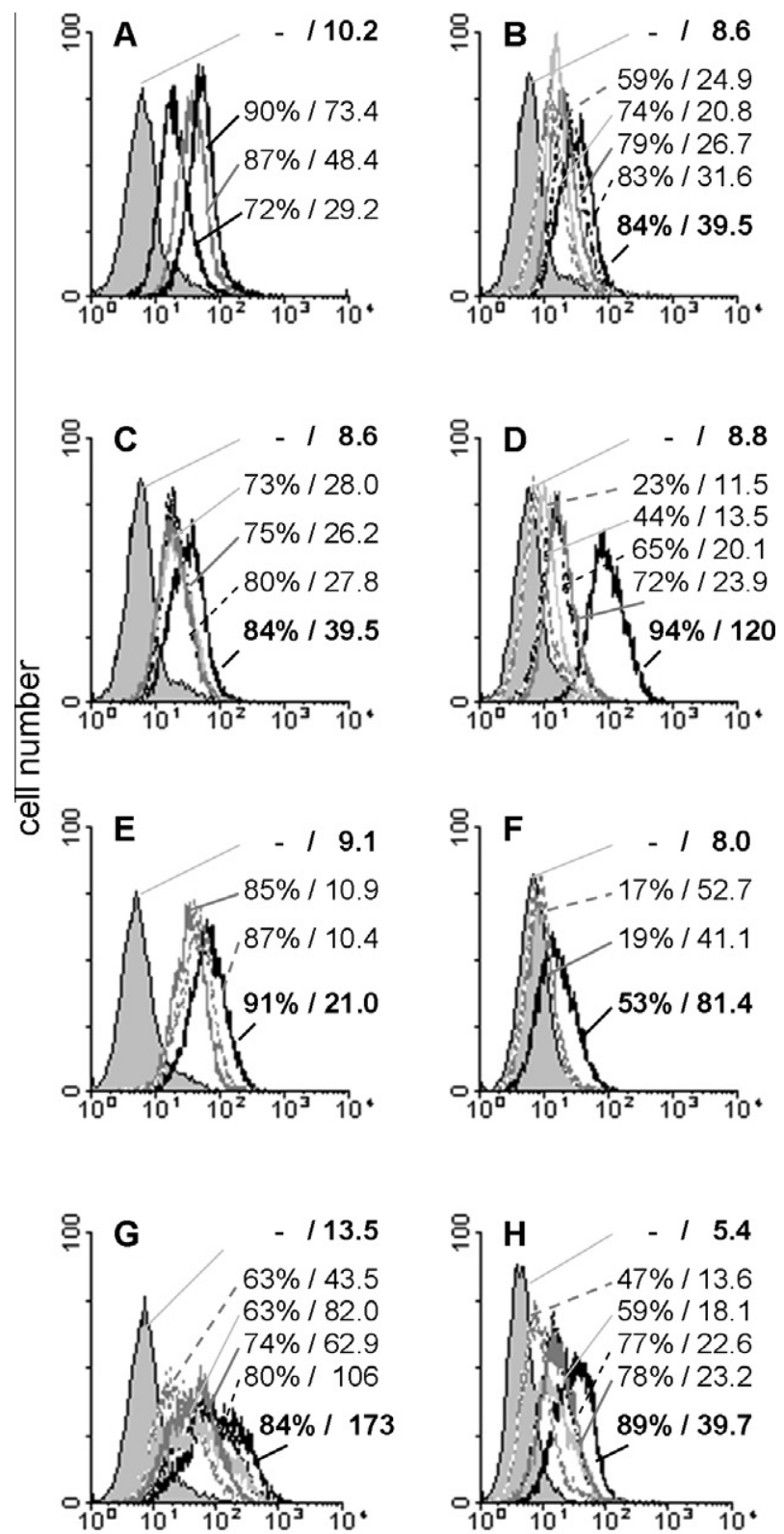

log fluorescence

Figure 3. Semilogarithmic representation of fluorescent surface staining of human tumor cells by labeled lectins. The control value representing marker-independent staining by incubation with the second-step reagent is given as shaded area, the $100 \%$-value obtained by lectin binding in the absence of test compound is shown as black line. Quantitative data on percentage of positive cells and mean fluorescence intensity are given in each panel (numbers for controls printed in bold). They are listed in increasing level of inhibitory potency from bottom to top as given in this text, and lines connect these data with the respective peak. The following pairs of human tumor cell line/biotinylated lectin were processed for the given set of compound/concentration: (A) T-cell leukemia cell line Jurkat and VAA at increasing concentrations of $1 \mu \mathrm{g} / \mathrm{ml}, 2 \mu \mathrm{g} / \mathrm{ml}$ and $4 \mu \mathrm{g} \mathrm{VAA} / \mathrm{ml}$ without an inhibitor; $(B, C)$ respective results at the constant lectin concentration of $2.5 \mu \mathrm{g}$ $\mathrm{VAA} / \mathrm{ml}$ in the presence of galactose and compounds 56, 59 and 60 (B) as well as lactose and compounds 29 and 24 (C) at $1 \mathrm{mM}$; (D, E) T-cell leukemia cell line Jurkat and $5 \mu \mathrm{g}$ galectin- $3 / \mathrm{ml}$ in the presence of $2 \mathrm{mM}$ compound $\mathbf{6}$, lactose and compound 59 and $1 \mathrm{mM} 60$ (D) and in the presence of $15 \mu \mathrm{M}$ compound 60 and $100 \mu \mathrm{M}$ lactose (E); (F) colon adenocarcinoma line SW480 and $2 \mu \mathrm{g}$ galectin-3/ml in the presence of $100 \mu \mathrm{M}$ lactose and $15 \mu \mathrm{M}$ compound $60 ;(\mathrm{G}, \mathrm{H})$ colon adenocarcinoma line SW480 and $1 \mu \mathrm{g}$ galectin- $8 / \mathrm{ml}(\mathrm{G})$ or $40 \mu \mathrm{g}$ galectin- $9 / \mathrm{ml}(\mathrm{H})$ in the presence of lactose and compounds 52, 59, and 60 at $2 \mathrm{mM}(\mathrm{G})$ and compound 52, lactose and compounds 59 and 60 at $2 \mathrm{mM}(\mathrm{H})$. Assays were performed in triplicates with up to five independent series using aliquots of cell suspensions at the same day with standard deviations not exceeding $10.8 \%$ after normalization of the data. to about $10 \%$ at $1 \mathrm{mM}$. Both compounds are listed in Table 1 with activity on galectin-3. The most active compound, that is, the trimeric lactoside 60 , also had an effect on proliferation, allowing $75 \%$ growth at $1 \mathrm{mM}$ and about $58 \%$ at $2 \mathrm{mM}$.

\section{Conclusions}

The presented data contribute to characterize the potential of carbohydrate derivatization to produce inhibitors of binding for two classes of galactoside-specific lectins. The assessment was based on testing a surface-presented neoglycoprotein and cell surfaces as ligands, the latter assay increasing the biorelevance. Using lactose as internal standard, our results reveal the inherent limits of the tested substitutions, although activity improvements were noted here and also in other cases. ${ }^{24,48,49}$ In addition, and even more important, interlectin cross-reactivity occurred. This finding is a strong argument to turn efforts to identify the natural substitutions favorable for high-affinity and selective binding and then to exploit them using the presented strategy. As binding assays with glycosylation mutants documented recently, galectins- 8 and -9 , to give an instructive example, can distinguish cell surfaces based on the level of $\alpha 2,3$-sialylation of $\mathrm{N}$-glycans, ${ }^{50}$ and the documented bioactivity of glycopeptides, too, can aid in increasing affinity and selectivity. ${ }^{51,52}$ The lack of cytotoxicity of natural glycans, derived from synthesis, ${ }^{53,54}$ should not be extrapolated to substituted derivatives, as our study clearly shows. Of further note, compared to the tested substitutions in monovalent compounds, an increase of valency appears to promote inhibitory potency more than a derivatization. Combining the slight activity increase by the $p$-isothiocyanate derivatization of lactose with multivalent display in starburst dendrimers had even resulted in up to 10,000 -fold enhancement for the plant toxin. ${ }^{55}$ Conformational flexibility/ rigidity of the scaffold, distinct cluster design and the structural context of the presentation of the carbohydrate headgroup can also make its mark on selectivity. ${ }^{39,56-60}$ In the family of galectins, the three different types of display of the lectin sites are thus becoming a target for suited glycocluster design, with the aim to team up headgroup design with these topological parameters for optimal affinity and selectivity. The availability of diverse scaffolds, whose biocompatibility has to be rigorously tested, as done for 0 -glycosyl carbamates, ${ }^{49}$ gives respective research a clear direction. ${ }^{61,62}$ Our strategically combined screening strategy comprising biochemical and cell biological assays will be helpful along this route.

\section{Materials and methods}

\subsection{Chemistry}

\subsubsection{General chemistry}

All reactions involving water-sensitive chemicals were carried out in flame-dried glassware with magnetic stirring under a nitrogen atmosphere. Anhydrous DCM was distilled from $\mathrm{CaH}_{2}$ and anhydrous THF from $\mathrm{Na} / \mathrm{K}$ prior to use. All non-aqueous reactions were carried out under anhydrous conditions within a nitrogen atmosphere in distilled solvents. Other solvents and reagents were used as received. TLC was performed on aluminum plates (Silica gel 60 F254) with detection by UV or by coloration with ammonium molybdate in acid solution. Column chromatography was performed on silica gel (230-400 mesh) with the indicated eluent. ${ }^{1} \mathrm{H}$ and ${ }^{13} \mathrm{C}$ NMR spectra were recorded at 300 (75) MHz with a Variant apparatus. Chemical shifts ( $\mathrm{ppm}$ ) are reported relative to $\mathrm{CHCl}_{3}$ (7.27), $\mathrm{D}_{2} \mathrm{O}$ or $\mathrm{CD}_{3} \mathrm{OD}$ as internal standard. Optical rotations were measured on a Polarimeter JASCO P-1000 and melting point on a Fisher-Johns Melting Point Apparatus. ESI-MS analyses were carried out on MICROMASS Quattro LC equipment. 


\subsubsection{Sources of the compounds of the chemical library}

Compounds in Schemes 1, 3 and 4 were part of the chemical library collection in one of the author laboratory (R. R.) and have been published elsewhere as follows: 1-2, ${ }^{36} \mathbf{3 3},{ }^{3} \mathbf{4 - 9},{ }^{36} \mathbf{1 0 - 1 1},{ }^{29}$ $12,{ }^{32} 13,{ }^{37} 14-32,{ }^{36} 41,45-46,{ }^{34} 51-55,{ }^{32} 56,{ }^{36} 57-58,{ }^{41} 59,{ }^{42}$ and finally compound $\mathbf{6 0} .^{29}$ Compounds $\mathbf{3 3 - 5 0}$ are new derivatives (see Supplementary data for a detailed account).

\subsection{Lectins}

Recombinant expression in the case of galectins and extraction of dried mistletoe leaves in the case of the plant toxin provided the starting material for lectin purification by affinity chromatography on lactosylated Sepharose 4B, obtained by divinyl sulfone activation, as crucial step, followed by purity controls using one- and two-dimensional gel electrophoresis, gel filtration and mass spectrometry and activity assay by haemagglutination as described. ${ }^{50,51,63,64}$ Biotinylation with the $N$-hydroxysuccinimide ester derivative of biotin (Sigma, Munich, Germany) under activity-preserving conditions and product analysis to determine extent of label incorporation by two-dimensional gel electrophoresis/ mass spectrometry were carried out as described. ${ }^{24}$ The labeled products were tested in standard solid-phase/cell assays to ascertain bioactivity and absence of non-specific interactions due to label incorporation (for experimental assay details, see below).

\subsection{Solid-phase inhibition assay}

The lectin-binding matrix was established by adsorption of lactosylated bovine serum albumin, exposing the $p$-isothiocyanatophenyl derivative (26 sugar units on average per carrier protein ${ }^{65}$ ), to the surface of microtiter plate wells from phosphatebuffered saline at $4{ }^{\circ} \mathrm{C}$ overnight. Following systematic titrations an optimal quantity of $0.25 \mu \mathrm{g}$ neoglycoprotein was routinely applied in $50 \mu \mathrm{l}$ for coating. Residual sites on the plastic surface with capacity for protein binding were saturated with a solution of the carrier protein free of contaminating glycoproteins (Biomol, Hamburg, Germany; $100 \mu \mathrm{l}, 1 \% \mathrm{w} / \mathrm{v})$ within $1 \mathrm{~h}$ at $37^{\circ} \mathrm{C}$. Lectin-containing solutions $(1 \mu \mathrm{g} / \mathrm{ml}$ and $3 \mu \mathrm{g} / \mathrm{ml}$ in the case of VAA, $20 \mu \mathrm{g}$ galectin- $1 / \mathrm{ml}, 10 \mu \mathrm{g}$ galectin- $3 / \mathrm{ml}, 0.1 \mu \mathrm{g}$ galectin$8 / \mathrm{ml}$ and $15 \mu \mathrm{g}$ galectin- $9 / \mathrm{ml}$, in all experimental series based on systematic titrations) in the absence (control) or presence of test compound (up to nine different concentrations) were incubated in the wells for $1 \mathrm{~h}$ at $37^{\circ} \mathrm{C}$ to enable binding of the labeled lectin, and the extent of lectin-neoglycoprotein complex formation was detected spectrophotometrically as described (for further information on number of experiments and standard deviations, please see footnote to Table 1$){ }^{24}$ The concentration of glycoclusters was routinely normalized to their sugar content to facilitate direct comparison to free lactose used as internal control.

\subsection{Cell-binding inhibition assay}

Cells of the human SW480 colon adenocarcinoma and the Jurkat T-cell leukemia lines were grown and processed in FACScan analysis using the fluorescent streptavidin/R-phycoerythrin complex (Sigma; 1:40) as indicator as described. ${ }^{24,66}$ Lectin concentrations given in the legend to Figure 3 were based on systematic titrations, each experimental series with synthetic compounds included the negative control (omission of the incubation step with labeled lectin) and the specificity controls with lactose/galactose. Two noncognate sugars were used to exclude osmolarity effects. Results are expressed in percentage of positive cells and mean fluorescence intensity (for further information on number of experiments and standard deviations, please see legend to Fig. 3).

\subsection{Cell proliferation assay}

The extent of growth of human SW480 colon adenocarcinoma cells after $48 \mathrm{~h}$ in culture was determined for aliquots of cell suspensions in the absence (control) and in the presence of test compounds including galactose and lactose spectrophotometrically using the blue chromogen 3-(4,5-dimethyl-thiazol-3-yl)-2,5-diphenyl-tetrazolium bromide (Sigma; $0.5 \mathrm{mg} / \mathrm{ml}$ ). ${ }^{67}$ Assays were performed in triplicates and in three independent series with standard deviations not exceeding $12.6 \%$.

\section{Acknowledgements}

The generous financial support by a Canadian Research Chair in Therapeutic Chemistry grant from the NSERC, the EC GlycoHIT program and the Verein zur Förderung des biologisch-technologischen Fortschritts in der Medizin e. V. (Heidelberg, Germany), inspiring discussions with Drs. B. Friday, S. Namirha, Y. Nekcic and W. Notelecs as well as the excellent assistance of Tze Chieh Shiao are gratefully acknowledged.

\section{A. Supplementary data}

Supplementary data associated with this article can be found, in the online version, at doi:10.1016/j.bmc.2011.03.022.

\section{References and notes}

1. The Sugar Code. Fundamentals of glycosciences; Gabius, H.-J., Ed.; Wiley-VCH: Weinheim Germany, 2009.

2. Imberty, A.; Chabre, Y. M.; Roy, R. Chem. Eur. J. 2008, 14, 7490.

3. Chabre, Y. M.; Roy, R. Curr. Top. Med. Chem. 2008, 14, 1237.

4. Rorive, S.; Belot, N.; Decaestecker, C.; Lefranc, F.; Gordower, L.; Micik, S.; Maurage, C.-A.; Kaltner, H.; Ruchoux, M.-M.; Danguy, A.; Gabius, H.-J.; Salmon, I.; Kiss, R.; Camby, I. Glia 2001, 33, 241.

5. Liu, Y.-H.; D’Ambrosio, M.; Liao, T.-D.; Peng, H.; Rhaleb, N. E.; Sharma, U. C.; André S.; Gabius, H.-J.; Carretero, O. A. Am. J. Physiol. Heart Circ. Physiol. 2009, $296, \mathrm{H} 404$.

6. Osborn, H. M. I.; Turkson, A. In The Sugar Code. Fundamentals of glycosciences; Gabius, H.-J., Ed.; Wiley-VCH: Weinheim, Germany, 2009. pp. 469-483.

7. Roda, O.; Ortiz-Zapater, E.; Martínez-Bosch, N.; Gutiérrez-Gallego, R. Vila-Perelló, M.; Ampurdanés, C.; Gabius, H.-J.; André, S.; Andreu, D.; Real, F. X.; Navarro, P. Gastroenterology 2009, 136, 1379.

8. Jiménez, M.; Sáiz, J. L.; André, S.; Gabius, H.-J.; Solís, D. Glycobiology 2005, 15 1386.

9. Villalobo, A.; Nogales-González, A.; Gabius, H.-J. Trends Glycosci. Glycotechnol. 2006, 18,1 .

10. Schwartz-Albiez, R. In The Sugar Code. Fundamentals of glycosciences; Gabius, H.-J., Ed.; Wiley-VCH: Weinheim Germany, 2009. pp. 447-467.

11. Sparrow, C. P.; Leffler, H.; Barondes, S. H. J. Biol. Chem. 1987, 262, 7383.

12. Galanina, O. E.; Kaltner, H.; Khraltsova, L. S.; Bovin, N. V.; Gabius, H.-J. J. Mol. Recognit. 1997, 10, 139.

13. Ahmad, N.; Gabius, H.-J.; Kaltner, H.; André, S.; Kuwabara, I.; Liu, F.-T.; Oscarson, S.; Norberg, T.; Brewer, C. F. Can. J. Chem. 2002, 80, 1096.

14. Hirabayashi, J.; Hashidate, T.; Arata, Y.; Nishi, N.; Nakamura, T.; Hirashima, M. Urashima, T.; Oka, T.; Futai, M.; Müller, W. E. G.; Yagi, F.; Kasai, K. I. Biochim. Biophys. Acta 2002, 1572, 232.

15. Dam, T. K.; Gabius, H.-J.; André, S.; Kaltner, H.; Lensch, M.; Brewer, C. F. Biochemistry 2005, 44, 12564.

16. He, L.; André, S.; Siebert, H.-C.; Helmholz, H.; Niemeyer, B.; Gabius, H.-J. Biophys. J. 2003, 85, 511.

17. Jiménez, M.; André, S.; Barillari, C.; Romero, A.; Rognan, D.; Gabius, H.-J.; Solís, D. FEBS Lett. 2008, 582, 2309.

18. He, L.; André, S.; Garamus, V. M.; Siebert, H.-C.; Chi, C.; Niemeyer, B.; Gabius H.-J. Glycoconjug. J. 2009, 26, 111

19. Göhler, A.; André, S.; Kaltner, H.; Sauer, M.; Gabius, H.-J.; Doose, S. Biophys. J. 2010, 98, 3044

20. Rini, J. M. Annu. Rev. Biophys. Biomol. Struct. 1995, 24, 551.

21. Roy, R. Trends Glycosci. Glycotechnol. 2003, 15, 289.

22. Kopitz, J.; Bergmann, M.; Gabius, H.-J. IUBMB Life 2010, 62, 624

23. Lee, Y. C. Trends Glycosci. Glycotechnol. 2010, 22, 95.

24. André, S.; Giguère, D.; Dam, T. K.; Brewer, C. F.; Gabius, H.-J.; Roy, R. New J. Chem. 2010, 34, 2229.

25. Lee, R. T.; Gabius, H.-J.; Lee, Y. C. J. Biol. Chem. 1992, 267, 23722.

26. Ahmed, H.; Allen, H. J.; Sharma, A.; Matta, K. L. Biochemistry 1990, 29, 5315

27. Lee, R. T.; Ichikawa, Y.; Allen, H. J.; Lee, Y. C. J. Biol. Chem. 1990, 265, 7864.

28. Giguère, D.; Sato, S.; St-Pierre, C.; Sirois, S.; Roy, R. Bioorg. Med. Chem. Lett. 2006 $16,1668$. 
29. Giguère, D.; Patnam, R.; Bellefleur, M.-A.; St-Pierre, C.; Sato, S.; Roy, R. Chem. Commun. 2006, 2379.

30. Sirois, S.; Giguère, D.; Roy, R. Med. Chem. 2006, 2, 481.

31. Lowary, T. L.; Hindsgaul, O. Carbohydr. Res. 1994, 251, 33

32. Béha, S.; Giguère, D.; Patnam, R.; Roy, R. Synlett 2006, 1739.

33. Patnam, R.; Juárez-Ruiz, J. M.; Roy, R. Org. Lett. 2006, 8, 2691.

34. Giguère, D. M. Sc. Thesis, Université du Québec à Montréal, 2006.

34. Giguère, D. M. Sc. Thesis, Université du Québec à Montréal, 2006.

36. Giguère, D.; Bonin, M.-A.; Cloutier, P.; Patnam, R.; St-Pierre, C.; Sato, S.; Roy, R Bioorg. Med. Chem. 2008, 16, 7811.

37. Giguère, D.; Patnam, R.; Juárez-Ruiz, J. M.; Neault, M.; Roy, R. Tetrahedron Lett. 2009, 50, 4254.

38. Vrasidas, I.; Kemmink, J.; Liskamp, R. M. J.; Pieters, R. J. Org. Lett. 2002, 4, 1807.

39. André, S.; Pieters, R. J.; Vrasidas, I.; Kaltner, H.; Kuwabara, I.; Liu, F.-T.; Liskamp, R. M. J.; Gabius, H.-J. ChemBioChem 2001, 2, 822.

40. Vrasidas, I.; André, S.; Valentini, P.; Böck, C.; Lensch, M.; Kaltner, H.; Liskamp, R. M. J.; Gabius, H.-J.; Pieters, R. J. Org. Biomol. Chem. 2003, 1, 803.

41. Lebaupain, F.; Salvay, A. G.; Olivier, B.; Durand, G.; Fabiano, A.-S.; Michel, N.; Popot, J.-L.; Ebel, C.; Breyton, C.; Pucci, B. Langmuir 2006, 22, 8881.

42. Polidori, A.; Pucci, B.; Maurizis, J. C.; Pavia, A. A. New. J. Chem. 1994, 18, 839.

43. Kopitz, J.; von Reitzenstein, C.; André, S.; Kaltner, H.; Uhl, J.; Ehemann, V.; Cantz, M.; Gabius, H.-J. J. Biol. Chem. 2001, 276, 35917.

44. Sanchez-Ruderisch, H.; Fischer, C.; Detjen, K. M.; Welzel, M.; Wimmel, A.; Manning, J. C.; André, S.; Gabius, H.-J. J. FEBS 2010, 277, 3552.

45. Ribeiro, J. P.; André, S.; Cañada, F. J.; Gabius, H.-J.; Butera, A. P.; Alves, R. J. Jiménez-Barbero, J. ChemMedChem 2010, 5, 415.

46. Muñoz, F. J.; Santos, J. I.; Ardá, A.; André, S.; Gabius, H.-J.; Sinisterra, J. V.; Jiménez-Barbero, J.; Hernáiz, M. J. Org. Biomol. Chem. 2010, 8, 2986.

47. Solís, D.; Romero, A.; Kaltner, H.; Gabius, H.-J.; Díaz-Mauriño, T. J. Biol. Chem. 1996, 271, 12744.

48. Sörme, P.; Arnoux, P.; Kahl-Knutsson, B.; Leffler, H.; Rini, J. M.; Nilsson, U. J. J. Am. Chem. Soc. 2005, 127, 1737.

49. André, S.; Specker, D.; Bovin, N. V.; Lensch, M.; Kaltner, H.; Gabius, H.-J.; Wittmann, V. Bioconjug. Chem. 2009, 20, 1716.
50. Solís, D.; Maté, M. J.; Lohr, M.; Ribeiro, J. P.; López-Merino, L.; André, S.; Buzamet, E.; Cañada, F. J.; Kaltner, H.; Lensch, M.; Ruiz, F. M.; Haroske, G.; Wollina, U.; Kloor, M.; Kopitz, J.; Sáiz, J. L.; Menéndez, M.; Jiménez-Barbero, J.; Romero, A.; Gabius, H.-J. Int. J. Biochem. Cell Biol. 2010, 42, 1019.

51. André, S.; Maljaars, C. E. P.; Halkes, K. M.; Gabius, H.-J.; Kamerling, J. P. Bioorg. Med. Chem. Lett. 2007, 17, 793.

52. Jiménez-Barbero, J.; Dragoni, E.; Venturi, C.; Nannucci, F.; Ardá, A.; Fontanella, M.; André, S.; Cañada, F. J.; Gabius, H.-J.; Nativi, C. Chem. Eur. J. 2009, 15, 10423.

53. André, S.; Kožár, T.; Kojima, S.; Unverzagt, C.; Gabius, H.-J. Biol. Chem. 2009, 390, 557.

54. Oscarson, S. In The Sugar Code. Fundamentals of glycosciences; Gabius, H.-J., Ed.; Wiley-VCH: Weinheim Germany, 2009. pp. 31-51.

55. André, S.; Ortega, P. J.; Perez, M. A.; Roy, R.; Gabius, H.-J. Glycobiology 1999, 9, 1253.

56. André, S.; Liu, B.; Gabius, H.-J.; Roy, R. Org. Biomol. Chem. 2003, 1, 3909.

57. André, S.; Sansone, F.; Kaltner, H.; Casnati, A.; Kopitz, J.; Gabius, H.-J.; Ungaro, R. ChemBioChem 2008, 9, 1649.

58. Leyden, R.; Velasco-Torrijos, T.; André, S.; Gouin, S.; Gabius, H.-J.; Murphy, P. J. Org. Chem. 2009, 74, 9010.

59. André, S.; Lahmann, M.; Gabius, H.-J.; Oscarson, S. Mol. Pharmaceut. 2010, 7, 2270.

60. Krzeminski, M.; Singh, T.; André, S.; Lensch, M.; Wu, A. M.; Bonvin, A. M. J. J.; Gabius, H.-J. Biochim. Biophys. Acta 2011, 1810, 150.

61. Chabre, Y. M.; Roy, R. In The Sugar Code. Fundamentals of glycosciences; Gabius, H.-J., Ed.; Wiley-VCH: Weinheim Germany, 2009. pp. 53-70.

62. Chabre, Y. M.; Roy, R. Adv. Carbohydr. Chem. Biochem. 2010, 63, 265.

63. Gabius, H.-J.; Engelhardt, R.; Cramer, F.; Bätge, R.; Nagel, G. A. Cancer Res. 1985 $45,253$.

64. Gabius, H.-J.; Walzel, H.; Joshi, S. S.; Kruip, J.; Kojima, S.; Gerke, V.; Kratzin, H.; Gabius, S. Anticancer Res. 1992, 12, 669.

65. Gabius, H.-J.; Bodanowitz, S.; Schauer, A. Cancer 1988, 61, 1125.

66. André, S.; Pei, Z.; Siebert, H.-C.; Ramström, O.; Gabius, H.-J. Bioorg. Med. Chem. 2006, 14,6314 .

67. Gabius, H.-J.; Darro, F.; Remmelink, M.; André, S.; Kopitz, J.; Danguy, A.; Gabius, S.; Salmon, I.; Kiss, R. Cancer Invest. 2001, 19, 114. 